\title{
Trophectoderm differentiation in the bovine embryo: characterization of a polarized epithelium
}

\author{
L. C. Barcroft ${ }^{1}$, A. Hay-Schmidt ${ }^{2}$, A. Caveney ${ }^{1}$, E. Gilfoyle ${ }^{1}$, E. W. Overstrom ${ }^{3}$, P. Hyttel ${ }^{2}$ \\ and A. J. Watson ${ }^{1}$ \\ ${ }^{1}$ Reproductive Biology Laboratories, Departments of Obstetrics and Gynaecology and Physiology, The University of Western Ontario, \\ London, Ontario, Canada N6A 5C1; ${ }^{2}$ Department of Anatomy and Physiology, The Royal Veterinary and Agricultural University, \\ Bulowsvej 13, Denmark DK-1870 Frederiksberg C; and ${ }^{3}$ Departments of Biomedical Sciences and Anatomy and Cellular Biology, \\ Tufts University, School of Veterinary Medicine, North Grafton, MA 01536, USA
}

\begin{abstract}
Blastocyst formation is dependent on the differentiation of a transporting epithelium, the trophectoderm, which is coordinated by the embryonic expression and cell adhesive properties of E-cadherin. The trophectoderm shares differentiative characteristics with all epithelial tissues, including E-cadherin-mediated cell adhesion, tight junction formation, and polarized distribution of intramembrane proteins, including the $\mathrm{Na}-\mathrm{K}$ ATPase. The present study was conducted to characterize the mRNA expression and distribution of polypeptides encoding E-cadherin, $\beta$-catenin, and the tight junction associated protein, zonula occludens protein 1, in pre-attachment bovine embryos, in vitro. Immunocytochemistry and gene specific reverse transcription-polymerase chain reaction methods were used. Transcripts for E-cadherin and $\beta$-catenin were detected in embryos of all stages throughout pre-attachment development. Immunocytochemistry revealed E-cadherin and $\beta$-catenin polypeptides evenly distributed around the cell margins of one-cell zygotes and cleavage stage embryos. In the morula, detection of these proteins diminished in the free apical surface of outer blastomeres. E-cadherin and $\beta$-catenin became restricted to the basolateral membranes of trophectoderm cells of the blastocyst, while maintaining apolar distributions in the inner cell mass. Zonula occludens protein 1 immunoreactivity was undetectable until the morula stage and first appeared as punctate points between the outer cells. In the blastocyst, zonula occludens protein 1 was localized as a continuous ring at the apical points of trophectoderm cell contact and was undetectable in the inner cell mass. These results illustrate that the gene products encoding E-cadherin, $\beta$-catenin and zonula occludens protein 1 are expressed and maintain cellular distribution patterns consistent with their predicted roles in mediating trophectoderm differentiation in in vitro produced bovine embryos.
\end{abstract}

\section{Introduction}

Transporting epithelia differentiate from apolar cells during development 'in concert' with the formation of epithelial junctional complexes (Boller et al., 1985; Gumbiner and Simons, 1987; Gumbiner et al., 1988), resulting in the establishment of distinct apical and basolateral plasma membrane domains (Vestweber et al., 1987; D'Angelo Siliciano and Goodenough, 1988; Fleming and Johnson, 1988; Rodrigez-Boulan and Nelson, 1989; Wiley et al., 1990; Watson, 1992; Watson et al., 1992a; Collins and Fleming, 1995). The epithelial junctional complexes are macromolecular structures consisting of zonula occludens (that is, tight junctions), zonula adherens (that is, adherent junctions), macula adherens (that is, desmosomes), and gap junctions (Fleming et al 1991, 1993; Citi, 1993; Kidder 1993). E-cadherin (uvomorulin) forms the main component of the

Revised manuscript received 14 April 1998. adherent junction, which is located at the lateral region of epithelial cell contact. Stable cell contacts and adhesion plaques are maintained via anchorage of $\mathrm{E}$-cadherin to the actin cytoskeleton through its cytoplasmic association with $\beta$-catenin, $\alpha$-catenin and $\gamma$-catenin (Nagafuchi and Takeichi, 1988; Kemler and Ozawa, 1989; Gumbiner and McCrea, 1993; McNeill et al., 1993; Ranscht, 1994). The requirement for Ecadherin during epithelial differentiation has been demonstrated through the transfection of non-epithelial cell lines with cadherins (Nagafuchi et al., 1987; Marrs et al., 1993). While cells transfected with E-cadherin polarize and adopt an epithelial phenotype, those transfected with the brain-associated cadherin, B-cadherin, do not undergo these differentiative events (Marrs et al., 1993).

The tight junction consists of a complex of at least five proteins: zonula occludens protein 1 (ZO-1), ZO-2, 7H6, cingulin and occludin (for review see Citi, 1993). Occludin is the core integral membrane protein interacting with ZO-1 (a 
$220 \mathrm{kDa}$ peripheral membrane protein) and cingulin to form a link between the tight junction and the cytoskeleton (Stevenson et al., 1986, 1988; Anderson et al., 1988; Citi et al., 1988, 1993; Furuse et al., 1993). At least two functions are served by the tight junction: the regulation of paracellular transport (the movement of water and solutes between epithelial cells) and the maintenance of epithelial cell polarity (Biggers et al., 1988; Stevenson et al., 1988; Watson, 1992; Citi, 1993).

Development of the early mammalian embryo to the blastocyst stage is dependent upon the differentiation of a transporting epithelium, the trophectoderm, required for the vectorial transport of fluids to form and sustain the blastocoel (Biggers et al., 1988; Watson, 1992; Kidder, 1993). The events of trophectoderm differentiation parallel those involved in the differentiation of all epithelia and are dependent upon the establishment of E-cadherin mediated cell-cell adhesion (Vestweber et al., 1987; Fleming and Johnson, 1988; Watson et al., 1990). While the expression patterns of junctional complex genes are well characterized in early mouse embryos (Vestweber et al., 1987; Larue et al., 1994; Reithmacher et al., 1995), this type of analysis has only just been initiated in embryos of other mammals (Reima et al., 1993; Shehu et al., 1996). Shehu et al. (1996) characterized the polypeptide distribution of a number of nuclear, cytoplasmic and extracellular proteins, including E-cadherin and ZO-1, in inseminated bovine oocytes transferred to ligated sheep oviducts. This system is reported to produce embryos that display identical characteristics of in vivo embryos with regard to morphology and pregnancy rates after transfer to recipient cows (Shehu et al., 1996). The present study examines the expression of these gene products in embryos produced exclusively within a culture environment. In addition, the expression of $\beta$-catenin gene products during bovine pre-attachment development has been examined for the first time. The present results demonstrate that gene products encoding E-cadherin, $\beta$ catenin and ZO-1 are expressed and maintain cellular distribution patterns consistent with their predicted roles in mediating trophectoderm differentiation in bovine embryos produced in vitro.

\section{Materials and Methods}

\section{Bovine embryo culture}

Bovine pre-attachment embryos were produced using standard in vitro oocyte maturation, fertilization and embryo culture methods (Wiemer et al., 1991; Watson et al., 1994; Winger et al., 1997). Cumulus-oocyte complexes (COCs) excised by razor blade from ovaries within $4 \mathrm{~h}$ of removal from the animal at an abattoir, were washed four times with oocyte collection medium (Hepes-buffered TCM-199 plus $2 \%$ newborn calf serum (NCS); Gibco, BRL, Burlington, ON). COCs were matured in TCM-199 medium plus $10 \%$ NCS supplemented with $35 \mu \mathrm{g}$ sodium pyruvate $\mathrm{ml}^{-1}$ (Sigma Chemical Co, St Louis, MO), $5 \mu \mathrm{g} \mathrm{FSH} \mathrm{m}^{-1}$ (Follitropin; Vetrapharm, London, $\mathrm{ON}$ ), $5 \mu \mathrm{g} \mathrm{LH} \mathrm{m}^{-1}$ (Vetrapharm) and 1 $\mu \mathrm{g}$ oestradiol ml $\mathrm{l}^{-1}$ (Sigma) for $22 \mathrm{~h}$ at $39^{\circ} \mathrm{C}$ in a humidified $5 \%$
$\mathrm{CO}_{2}$ in air atmosphere. Matured oocytes were fertilized in vitro with frozen-thawed bovine semen (Semex Canada Inc, Guelph, ON) prepared using a 'swim-up' method in sperm TL medium (Hepes-buffered modified Tyrodes solution; Parish et al., 1986). Matured COCs were washed in sperm TL and placed in equilibrated fertilization drops (50 COCs per $300 \mu \mathrm{l}$ drop) composed of bicarbonate-buffered modified Tyrodes solution under light paraffin oil (BDH Inc., Toronto, $\mathrm{ON})$. COCs and spermatozoa $\left(2.25 \times 10^{5}\right.$ motile spermatozoa per drop) were incubated for $18 \mathrm{~h}$ at $39^{\circ} \mathrm{C}$ under $5 \% \mathrm{CO}_{2}$ in air before removal of the cumulus investment with a fine bored glass pipette. Inseminated oocytes were co-cultured in $50 \mu \mathrm{l}$ culture micro-drops (TCM-199 plus 10\% NCS) under oil with 25-30 primary oviduct cell vesicles ( $\mathrm{Xu}$ et al., 1992; Harvey et al., 1995; Xia et al., 1996) and were supplemented with an additional $50 \mu 1$ TCM-199 plus $10 \%$ NCS medium after $48 \mathrm{~h}$ of culture to support development to the blastocyst stage.

\section{RNA isolation}

Total RNA was extracted from bovine embryos according to the method of Temeles et al. (1994). Bovine embryos were allocated into pools of one-cell zygotes, two-five cell embryos, six-eight cell embryos, morulae (day 6 after insemination), and blastocysts (day 8 after insemination). Pools of 50-100 embryos were lysed at room temperature in $100 \mu$ of GITC buffer (4 mol guanidinium isothiocyanate $\mathrm{l}^{-1}$; Pharmacia, Quebec, PQ; 0.1 mol Tris- $\mathrm{HCl} \mathrm{l}^{-1}, \mathrm{pH} 7.4 ; 1 \mathrm{~mol} 2-\beta$ mercaptoethanol $\mathrm{l}^{-1}$; Sigma) in the presence of $20 \mu \mathrm{g}$ of Escherichia coli rRNA (Gibco, BRL). Samples were vortexed vigorously and either frozen and stored at $-70^{\circ} \mathrm{C}$ or processed by ethanol precipitation before DNase digest. The precipitated samples were centrifuged at $10000 \mathrm{~g}$ for $20 \mathrm{~min}$ at room temperature; the pellets were washed twice with cold $70 \%$ ethanol and air dried before re-suspension in $20 \mu \mathrm{l}$ re-suspension buffer $\left(40 \mathrm{mmol}\right.$ Tris- $\mathrm{HCl} \mathrm{l}^{-1}$, $\mathrm{pH} \mathrm{7.9;10} \mathrm{mmol}$ $\mathrm{NaCl} \mathrm{l}^{-1} ; 6$ mmol $\mathrm{MgCl}_{2} \mathrm{l}^{-1}$ ). Genomic DNA was degraded by incubating the samples with 1 unit of RQ1 DNase (Promega, Biotec, Madison, WI) for $30 \mathrm{~min}$ at $37^{\circ} \mathrm{C}$. Samples were then re-extracted with phenol and re-precipitated with ethanol before the suspension of digested pellets in $10 \mu \mathrm{l}$ autoclaved MilliQ water. Oviductal total RNA was isolated by the same method without addition of E. coli rRNA and was quantified via spectrophotometry. Aliquots of $1 \mu \mathrm{g}$ oviduct cell total RNA was used for reverse transcription.

\section{Reverse transcription and polymerase chain reaction}

Total RNA was reverse-transcribed (RT) using oligo (dT) priming and Superscript ${ }^{\mathrm{TM}}$ Reverse Transcriptase (Gibco, BRL; Harvey et al., 1995; Watson et al., 1992b, 1994). RNA samples were incubated with $0.5 \mu \mathrm{g}$ Oligo $(\mathrm{dT})_{12-18}$ primer (Gibco, BRL) for $10 \mathrm{~min}$ at $70^{\circ} \mathrm{C}$. After cooling on ice, RNA was incubated in First Strand Buffer (Gibco, BRL; containing $50 \mathrm{mmol}$ Tris- $\mathrm{HCl} \mathrm{1} 1^{-1}$, $\mathrm{pH} 8.3,75 \mathrm{mmol} \mathrm{KCl} \mathrm{l}^{-1}, 3 \mathrm{mmol}$ $\mathrm{MgCl}_{2} \mathrm{l}^{-1}$, $10 \mathrm{mmol}$ dithiothreitol (DTT) $\mathrm{l}^{-1}, 0.5 \mathrm{mmol}$ dNTPs $^{-1}$ ) and 200 units of Superscript ${ }^{\mathrm{TM}}$ Reverse 
Transcriptase (Gibco, BRL) for $1.5 \mathrm{~h}$ at $43^{\circ} \mathrm{C}$. The reaction was terminated by heating at $94^{\circ} \mathrm{C}$ for $4 \mathrm{~min}$ and flash cooling on ice. Newly produced cDNA was further diluted with sterile distilled water to a concentration of two embryo equivalents per $\mu \mathrm{l}$ or the equivalent of $40 \mathrm{ng}$ of oviduct RNA mlPolymerase chain reaction (PCR) was performed as described previously (Watson et al., 1992b, 1994; Betts et al., 1997). Aliquots of embryo and oviductal cDNA $(2.5 \mu \mathrm{l}$ of a $50 \mu \mathrm{l}$ cDNA sample) were amplified with 1 unit of Taq DNA polymerase (Gibco, BRL) in a final volume of $50 \mu \mathrm{l}$ containing $10 \times$ PCR buffer $\left(200 \mathrm{mmol}\right.$ Tris $-\mathrm{HCl} \mathrm{l}^{-1}, \mathrm{pH} 8.8$, $500 \mathrm{mmol} \mathrm{KCl}^{-1}$ plus $1.0-2.0 \mathrm{mmol} \mathrm{MgCl}_{2} \mathrm{l}^{-1}, 0.2 \mathrm{mmol} \mathrm{l}^{-1}$ of each dNTP and $2 \mathrm{mmol} \mathrm{l}^{-1}$ of each gene-specific primer). The reaction mixture was covered with light paraffin oil and amplified for up to 40 cycles in a DNA thermal cycler (Perkin Elmer Cetus 480), with each cycle consisting of denaturation at $94^{\circ} \mathrm{C}$ for $1 \mathrm{~min}$, re-annealing of primers to target sequences at $50-56^{\circ} \mathrm{C}$ for $30 \mathrm{~s}$ and primer extension at $72^{\circ} \mathrm{C}$ for $1 \mathrm{~min}$. PCR products were resolved on $2 \%$ agarose gels containing 0.5 mg ethidium bromide $\mathrm{ml}^{-1}$.

\section{Polymerase chain reaction primers}

Primer sequences for actin, E-cadherin, and $\beta$-catenin were designed from CDNA sequences retrieved from GENBANK and were synthesized by Gibco, BRL (Burlington ON; see Table 1 for sequences). cDNA samples were tested for the presence of genomic DNA contamination before use in genespecific RT-PCR using a set of primers designed to bracket an intron of the $\beta$-actin cDNA. In the absence of genomic DNA, this primer set produces a $243 \mathrm{bp}$ amplification product (Watson et al., 1992b, 1994; Harvey et al., 1995). All cDNA samples used in the present study displayed amplification of the appropriate sized $\beta$-actin CDNA PCR product. Identity of the products produced by PCR reaction was verified using dye-coupled sequencing performed by GenAlyTiC (University of Guelph, ON) for each primer set.

\section{Immunocytochemistry}

Characterization of E-cadherin, $\beta$-catenin and ZO-1 polypeptides was conducted simultaneously in Danish and
Canadian laboratories. Two distinct methods of immunolocalization were used, consisting of wholemount confocal immunofluorescence and peroxidase diaminobenzidine immunocytochemistry. This strategy provided a unique opportunity to compare two methods of analysis and confirm the observed distribution patterns.

Wholemount indirect immunofluorescence. The following antisera were used: (1) a mouse monoclonal IgG2a (clone 36) raised against human E-cadherin (Transduction Laboratories, Mississauga, ON; 1:100 dilution); (2) a mouse monoclonal IgG1 (clone 14) directed against mouse $\beta$-catenin (Transduction Laboratories; 1:400 dilution); and (3) a rat monoclonal anti-ZO-1 antiserum (Chemicon, Mississauga, ON; 1:100 dilution). Wholemount immunofluorescence was applied to bovine embryos according to modifications of previous methods (De Sousa et al., 1993; Betts et al., 1997). Bovine embryos (from the one-cell stage to the blastocyst stage) were collected, washed twice in cold $1 \times$ PBS. Embryos were fixed through a methanol-PBS series consisting of 1:1 MeOH-PBS for $2 \mathrm{~min}, 2: 1 \mathrm{MeOH}-\mathrm{PBS}$ for $2 \mathrm{~min}$ and transfer into $600 \mu \mathrm{l}$ PBS containing $0.002 \%(\mathrm{v} / \mathrm{v})$ Triton X-100 for $5 \mathrm{~min}$ to allow the embryos to sink to the bottom of the chamber. Fixed embryos were washed in $1 \times$ PBS and either stored at $4^{\circ} \mathrm{C}$ for up to 1 week or were further processed immediately. Embryos processed for ZO-1 and $\beta$-catenin immunofluorescence were permeabilized in blocking solution $\left(0.01 \%(\mathrm{v} / \mathrm{v})\right.$ Triton X-100, $0.1 \mathrm{~mol}$ lysine $\mathrm{l}^{-1}$ and $1 \%$ $(\mathrm{v} / \mathrm{v})$ goat serum in PBS) for $45 \mathrm{~min}$ at room temperature and washed three times in fresh PBS. Embryos processed for Ecadherin immunofluorescence were not subjected to Triton $\mathrm{X}-100$ extraction. Embryos were incubated overnight at $4^{\circ} \mathrm{C}$ with primary antiserum (diluted in $0.002 \%(\mathrm{v} / \mathrm{v})$ Triton X-100 plus $1 \%$ goat serum in PBS) and washed four times in $0.002 \%$ (v/v) Triton X-100 plus $1 \%$ goat serum, with the final wash lasting 4-6 h. Samples were then incubated in secondary antisera consisting of either fluorescein isothiocyanate (FITC)-conjugated rabbit anti-mouse IgG secondary antibody (ICN Biochemicals, Montreal, PQ; 1:50 dilution) or FITC-conjugated goat anti-rat secondary antibody (ICN Biochemicals; $1: 100$ dilution) in $0.002 \%(\mathrm{v} / \mathrm{v})$ Triton X-100 plus $1 \%$ goat serum in PBS for $2 \mathrm{~h}$ at room temperature. Embryos were washed three times in fresh PBS for $10 \mathrm{~min}$ and left overnight in a final wash of $0.002 \%(\mathrm{v} / \mathrm{v})$ Triton X-100

Table 1. PCR primer sequences

\begin{tabular}{|c|c|c|c|c|}
\hline $\begin{array}{l}\text { PCR } \\
\text { Product }\end{array}$ & Primer Sequences & $\begin{array}{l}\text { Amplicon position } \\
\text { and size } \\
\text { (bp) }\end{array}$ & $\begin{array}{l}\text { Genbank } \\
\text { Accession } \\
\text { Number }\end{array}$ & References \\
\hline$\beta$-catenin & $\begin{array}{l}\text { 5'-primer = } \\
\text { GGTGCCATTCCACGACTAGTT } \\
\text { 3'-primer }= \\
\text { CAGCAGTCTCATTCCAAGCCA }\end{array}$ & $\begin{array}{l}\text { 1791-2283 of human } \\
\text { cDNA }=473\end{array}$ & emb|Z19054 & $\begin{array}{l}\text { Hulsken et al., } 1994 \\
\text { Nollet et al., } 1996\end{array}$ \\
\hline E-cadherin & $\begin{array}{l}\text { 5'-primer }= \\
\text { TGAGGCCAAGCAGCAATACA } \\
3^{\prime} \text {-primer }= \\
\text { TGCTGTTCTTCACATGCTCA }\end{array}$ & $\begin{array}{c}1405-1751 \text { of mouse } \\
\text { cDNA }=350\end{array}$ & emblX06115 & Nagafuchi et al., 1987 \\
\hline
\end{tabular}


plus $1 \%$ goat serum in PBS before a final transfer onto glass slides in $20 \mu \mathrm{l}$ of Fluoro-Guard (BioRad, Mississauga, ON) mounting medium under elevated $22 \times 22 \mathrm{~mm}$ glass slides sealed with nail polish. Slides were viewed on a BioRad MRC 600 confocal laser scanning microscope (BioRad). The procedures were repeated as many as six times for each embryo stage and, in total, approximately 100 embryos of each stage were examined.

Peroxidase diaminobenzidine staining. Embryos from the onecell to the blastocyst stage were collected for analysis of Ecadherin, $\beta$-catenin, and ZO- 1 distributions by application of peroxidase-diaminobenzidine (DAB) immunocytochemistry (Hay-Schmidt, 1995). In total, 15 embryos of each stage were examined, representing a total of 150 embryos for each antiserum. The zona pellucida was removed by incubating embryos in acid Tyrode's buffer ( $\mathrm{pH} 2.1$ ) for 1-3 min. After removal of the zona pellucida, embryos were washed in TCM-199 media at $39^{\circ} \mathrm{C}$ for $10 \mathrm{~min}$ and fixed in $4 \%(\mathrm{w} / \mathrm{v})$ paraformaldehyde in $0.1 \mathrm{~mol}$ phosphate buffer $\mathrm{l}^{-1}$ for $24 \mathrm{~h}$ at $4^{\circ} \mathrm{C}$. Fixed embryos were stored in PBS with $0.1 \%(\mathrm{v} / \mathrm{v})$ Triton $\mathrm{X}-100$ and $0.1 \%(\mathrm{w} / \mathrm{v})$ sodium azide at $4^{\circ} \mathrm{C}$. Identical primary antisera for $E$-cadherin and $\beta$-catenin were used in these studies as described above. For immunocytochemistry, these antiserum were diluted 1:2000 in PBS with $0.1 \%(\mathrm{v} / \mathrm{v})$ Triton $\mathrm{X}-100$ (PBST). For these studies, a rabbit polyclonal ZO-1 primary antiserum (Zymed, San Francisco, CA) was diluted 1:3000 in PBST. For each antiserum, embryos were incubated overnight at $4{ }^{\circ} \mathrm{C}$ with the primary antibody and washed three times in PBST. Embryos were then co-incubated with rabbitanti-mouse-biotinylated and swine-anti-rabbit-biotinylated secondary antibodies (diluted 1:500 in PBST) for 2-4 h at $4^{\circ} \mathrm{C}$ and then incubated for $1 \mathrm{~h}$ at room temperature. Embryos were washed three times in PBST and incubated in avidin-biotin complex ( $\mathrm{ABC}$; Vector, Burlingame, $\mathrm{CA}$ ) for $1-3 \mathrm{~h}$ at $4^{\circ} \mathrm{C}$ and $1 \mathrm{~h}$ at room temperature and then washed a further three times in PBST. ABC-treated embryos were incubated in $0.05 \%(\mathrm{w} / \mathrm{v}) \mathrm{DAB}$ without perhydrol for $15 \mathrm{~min}$, then incubated for 3-12 min in DAB plus perhydrol at room temperature. The $\mathrm{DAB}$ reaction was stopped by two washes in water. Subsequently, embryos were dehydrated, eponembedded and serial sectioned in $2 \mu \mathrm{m}$ sections, and every second section was stained with toluidine blue.

\section{Immunochemistry controls}

All of the antisera used in this study were obtained from commercial sources and their efficacy in specifically recognizing epitopes unique to their individual polypeptides has been determined by both western blot and in situ immunolocalization methods (Stevenson et al., 1986; Takeichi, 1988; Li and Poznansky, 1990; Ozawa et al., 1990; Behrens et al., 1993; Su et al., 1993). Routine controls were conducted to ensure that the experimental conditions were optimal. These controls included testing each antiserum first on untreated bovine tissue sections. Secondary antibody controls were conducted in which the primary antiserum was omitted to determine background fluorescence or DAB staining. Methanol fixation of whole-mount bovine embryos was used, as this method of fixation results in lower background autofluorescence and increased antigenicity compared with aldehyde fixatives (Davis, 1993). The immunofluorescence distributions were consistently observed among experimental replicate embryo pools for each embryo stage.

\section{Results}

\section{E-cadherin, and $\beta$-catenin transcripts during bovine pre- attachment development}

Transcripts encoding E-cadherin, and $\beta$-catenin (indicated by amplicons having the predicted sizes of 350 and $473 \mathrm{bp}$, respectively) were detected in one-cell bovine zygotes through to blastocyst stages (Fig. 1). In each case, the distribution of these transcripts suggests that these gene products are of both maternal and embryonic origin. Bovine RT-PCR products were sequenced to confirm the identity and contrast nucleotide sequence identity among species. Bovine RT-PCR products amplified using E-cadherin and $\beta$ catenin primers possessed $83 \%$ and $98 \%$ sequence identity with corresponding murine and human mRNA sequences, respectively (Fig. 2). An identical strategy for detecting transcripts encoding $\mathrm{ZO}-1$ during this developmental interval was attempted. Experiments were conducted with three separate primer sets designed to recognize conserved regions of mouse and human $\mathrm{ZO}-1 \mathrm{cDNAs}$. For each primer set, a series of PCR amplicons from bovine pre-attachment embryo stages was produced (data not shown). However, these products were not of the expected size and, upon

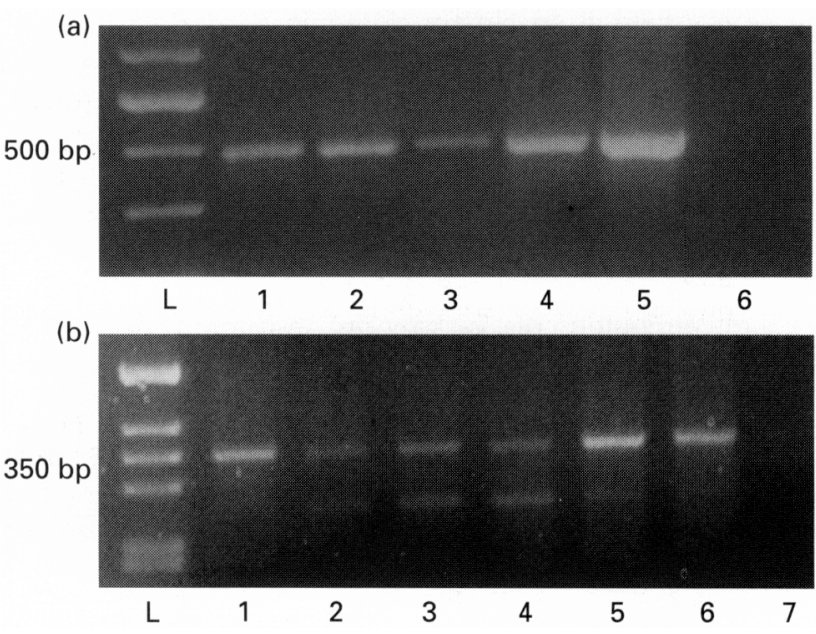

Fig. 1. Detection of transcripts encoding E-cadherin and $\beta$-catenin in bovine pre-attachment embryos. cDNA samples were amplified by 40 cycles of polymerase chain reaction. (a) $\beta$-catenin lanes are: $L$, $100 \mathrm{bp}$ DNA ladder (bands from top to bottom: $700 \mathrm{bp}, 600 \mathrm{bp}$, $500 \mathrm{bp}, 400 \mathrm{bp}$ ); 1, one-cell zygote; 2, 2-5-cell embryo; 3, 6-8-cell embryo; 4, morula; 5, blastocyst; 6 , negative control (no cDNA). (b) E-cadherin lanes are: $\mathrm{L}, 1 \mathrm{~kb}$ DNA ladder (bands from top to bottom: $516 / 506$ bp; 394 bp; 344 bp; 298 bp; 220/200 bp; 154/142 bp); 1, day 2 bovine oviduct monolayer; 2 , one-cell zygote; 3 , 2-5-cell embryo; 4 , 6-8-cell embryo; 5, morula; 6 , blastocyst; 7 , negative control. 
$\beta-$ Catenin

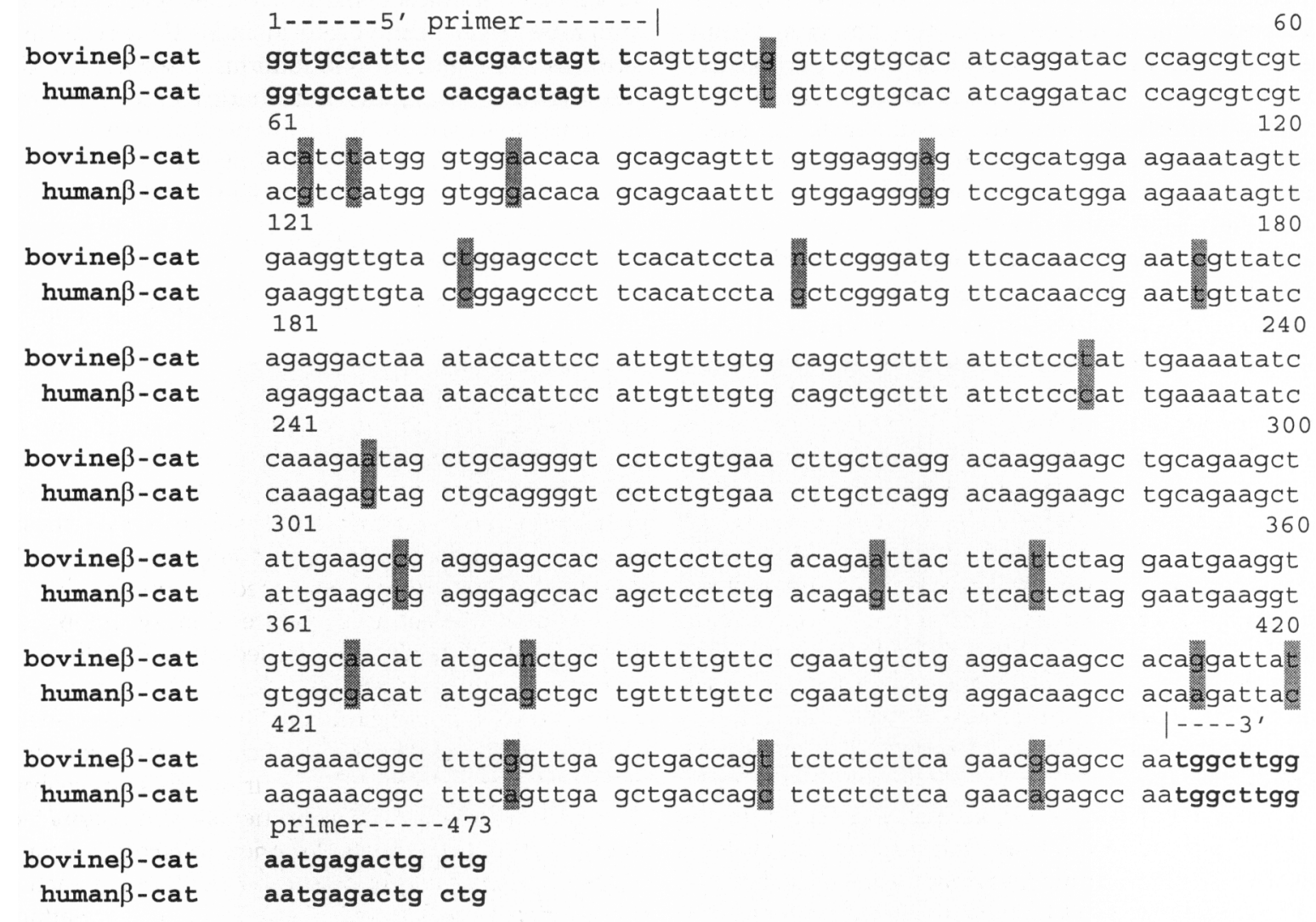

\section{E-Cadherin}

1260

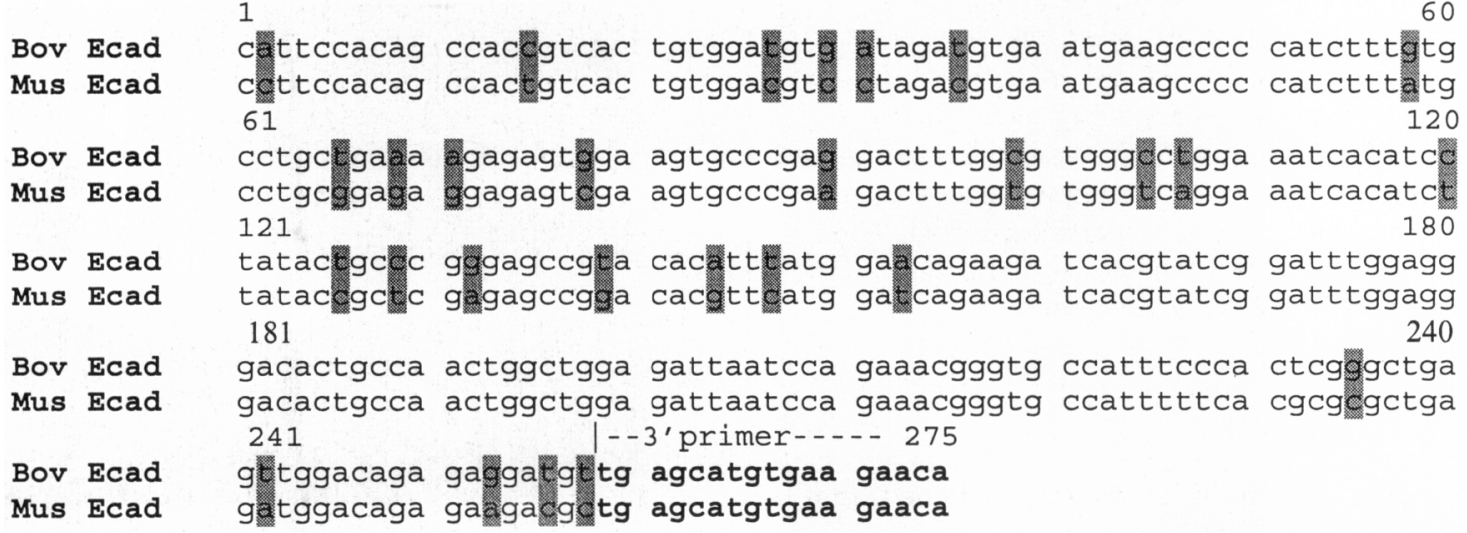

Fig. 2. Bovine $\beta$-catenin and E-cadherin reverse transcription-polymerase chain reaction (RT-PCR) amplicon sequences. Nucleotide sequences of bovine embryo products were compared with the corresponding human ( $\beta$-catenin) and mouse (E-cadherin) cDNA sequences. Specific primer sequences and areas of non-conserved bases are highlighted. The bovine $\beta$-catenin cDNA sequence shares $98 \%$ sequence homology with the human cDNA sequence. Analysis of 275 bp of the bovine E-cadherin cDNA by direct sequencing of PCR products demonstrated $83 \%$ homology to the known mouse cDNA sequence.

cloning and sequence analysis, did not share any homology with known ZO-1 cDNAs. For these reasons, it is the opinion of the authors that characterization of ZO-1 transcripts during early bovine development must await cloning and sequencing of the bovine $\mathrm{ZO}-1$ gene.
E-cadherin, $\beta$-catenin and ZO-1 polypeptides during bovine pre-attachment development

E-cadherin and $\beta$-catenin immunofluorescence was detected encircling the cell margins of each blastomere in 
one-cell aygotes through to the morula stage (Fign 3 and ta-f). The fluorescence was confined to the cell periphery and little cytoplasmic or nuclear signal was observed exept in morulat where $\beta$-catenin was evident in the perinuciear cytoplasm (Fig. $4(0)$. L-cadherin and $\beta$-catenin immunefluorescence diminished in the free apical surface of outer blastomeres in the morula, becoming undetectable in the apical surfaces of both mural and polar trophectoderm in the blastocyst (Fig. 5a,b), and confined to the basolateral membranes of trophectoderm alls and also encircling the cell periphery of each inner cell mass (ICM) all (Ficr. $3 a, b$ ).
The fluoresome patterm displased by E-cadherin and $\beta$ catenin antinera were consistently observed in all blastocysts and were nester observed to include the apical membrane surfaces of the trophestoderm. flowerer, immunofluorescence for both E-cadherin and $\beta$-catenin did demonstrate wariations in the intensity of immunostaining in the ICM of approximately 10" of blastoceste for both of these polvpeptides (data not shown). In the peroxidase-AB staned combrom, perinuelear staining for F-cadherin was observed from the four-cell to the fo-coll stage (Fig 6a-c). At the hatehed blastocest stage, E-coutherin was localized to the
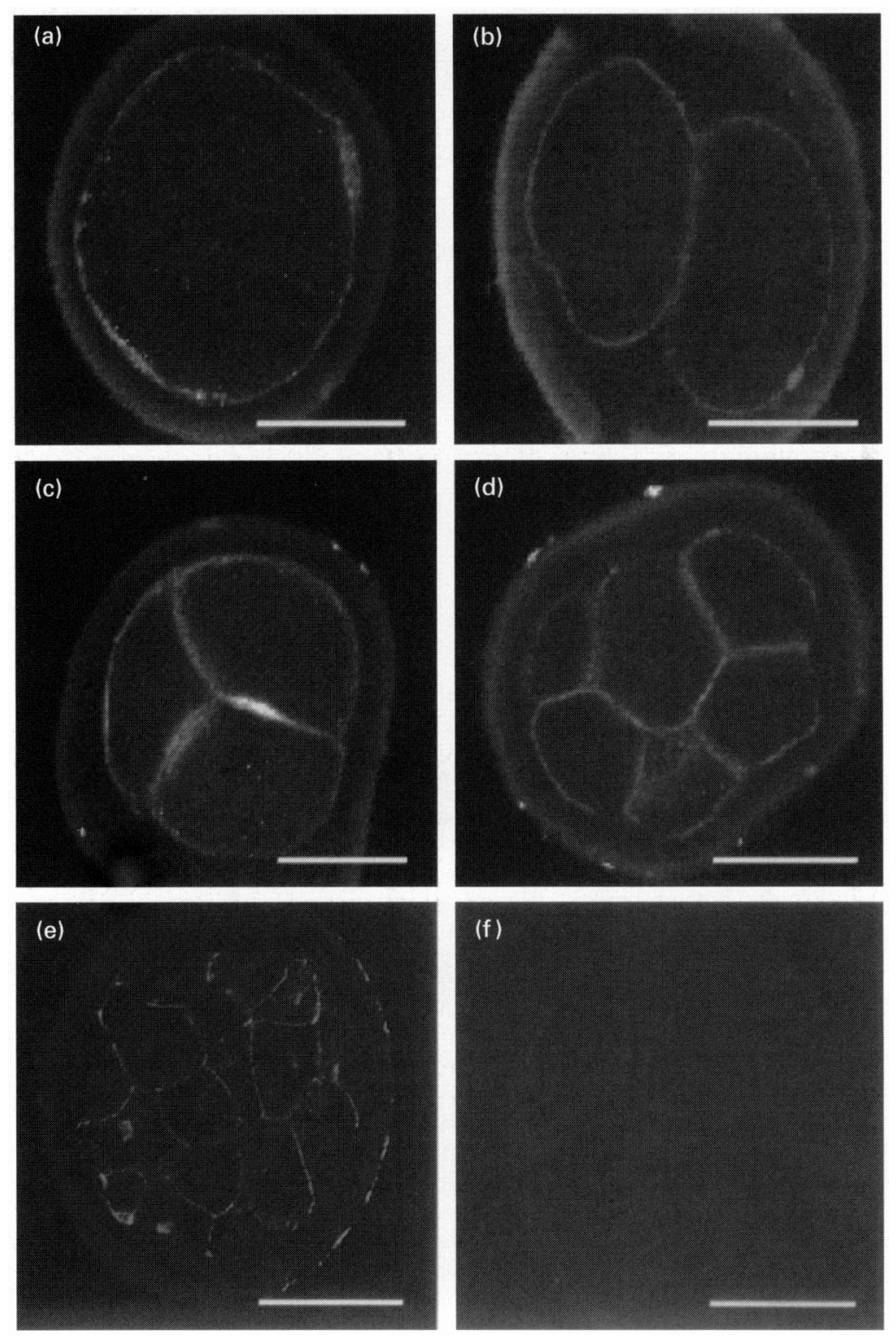

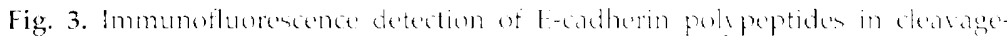

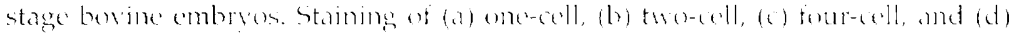

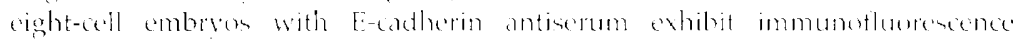

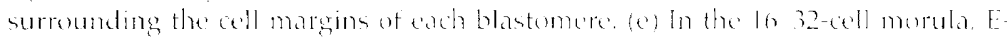

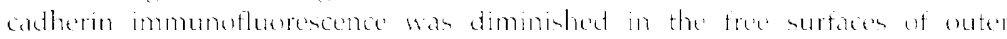

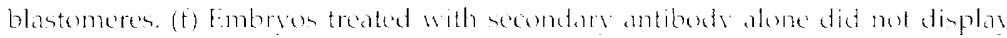
any fluorescence. All images are 1, im thick confocal laser wanning propections. scalebars reprenent $90 \mathrm{~mm}$ 

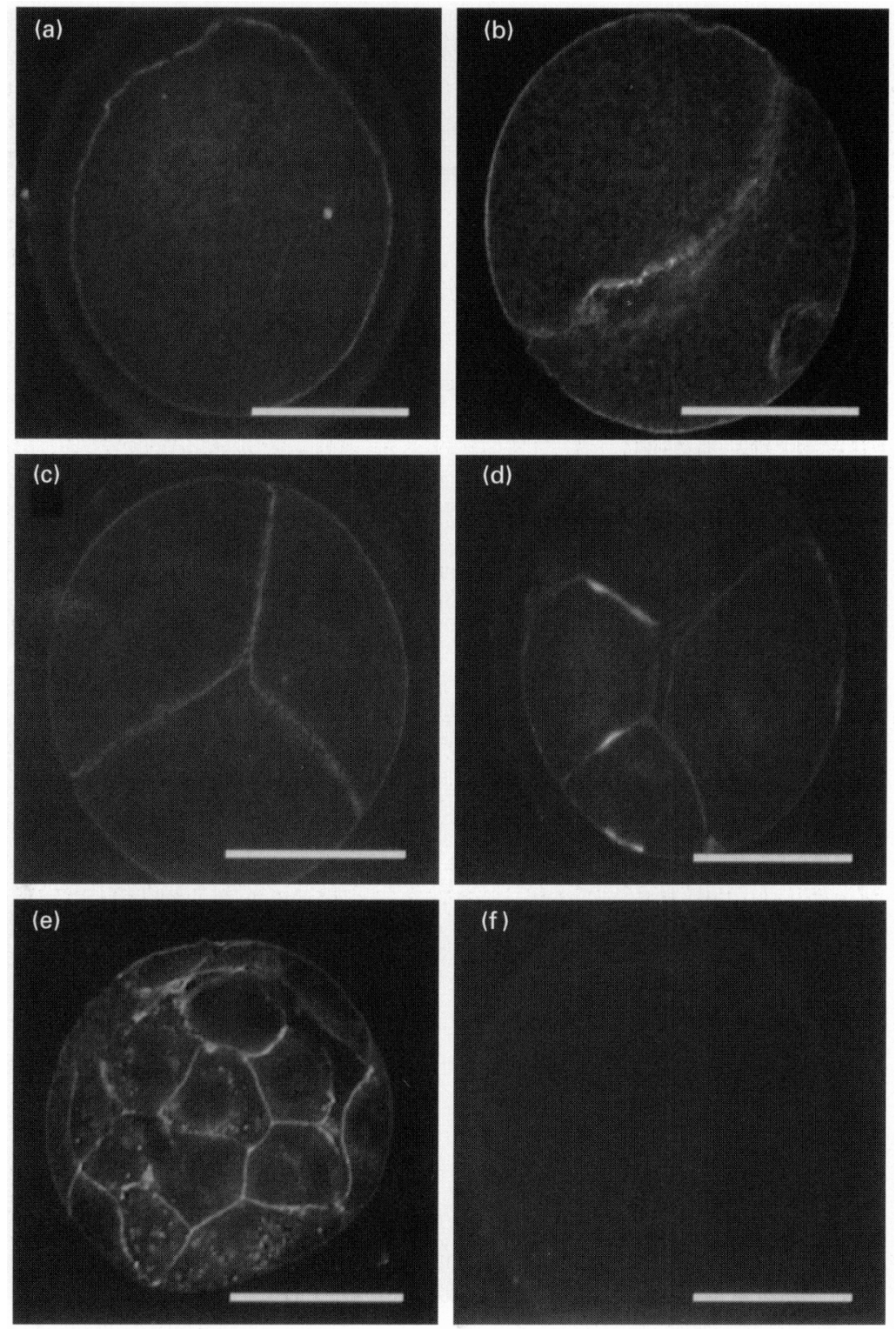

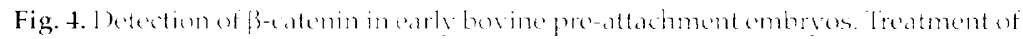

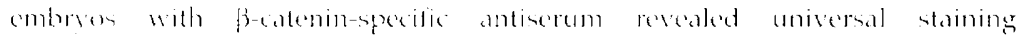

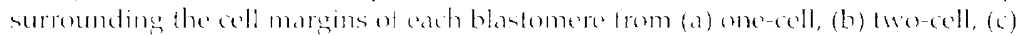

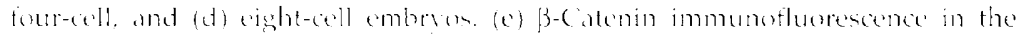

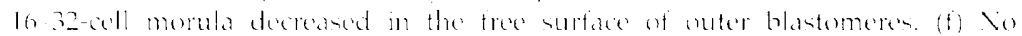

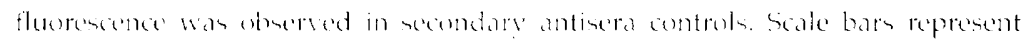
(2) 1111$)$.

lateral regions of trophectoderm all maggins extending from the ZO-1 staining to basal regions adjacent to the blastocoel cavity with sparse staining observed in the ICM cell periphery confined to cell contacts. Peroxidese- $) A B$ staining for B-catenin was observed from the worecoll stase at coll-coll contacts (Fig. od-gr). In hatched blastoeyste, staining was localized over the basolateral cell regions of the trophectoderm and encircling all margins of the ICM colls (Fig. 6t, gr).

In contrast to the distinct membrane associated localization of E-cadherin and $\beta$-catenin, no immunofluorescence signal was deteded for 7.)- - in identical poobs of early cleavage stage bowine embryos (Figr. 7a-f). ZO-1 immunofluorescence was first detected at the morula stage, appearing as punctate fluoresoent points between the outer colls (Iig . 70 ). The ZO-1 fluoreseence underwent a marked transition from the morula to the blastoryst stage (Fig. $8 \mathrm{a}-\mathrm{d}$ ). By the late morula, regioms of continuous fluorescence became apparent at revions of ecll contact between the outer cells of the embrvo (Fig. 8a). As cavitation progressed, $\mathrm{ZO}$-1 immunofluerescence became distinctly localized to apical regions of cell contact (Fig. sb), eventually forming a continuous fluoreseent ring confined to the apical points of trophedederm all contact (Fiss 8d and 6k). No fluorescence 

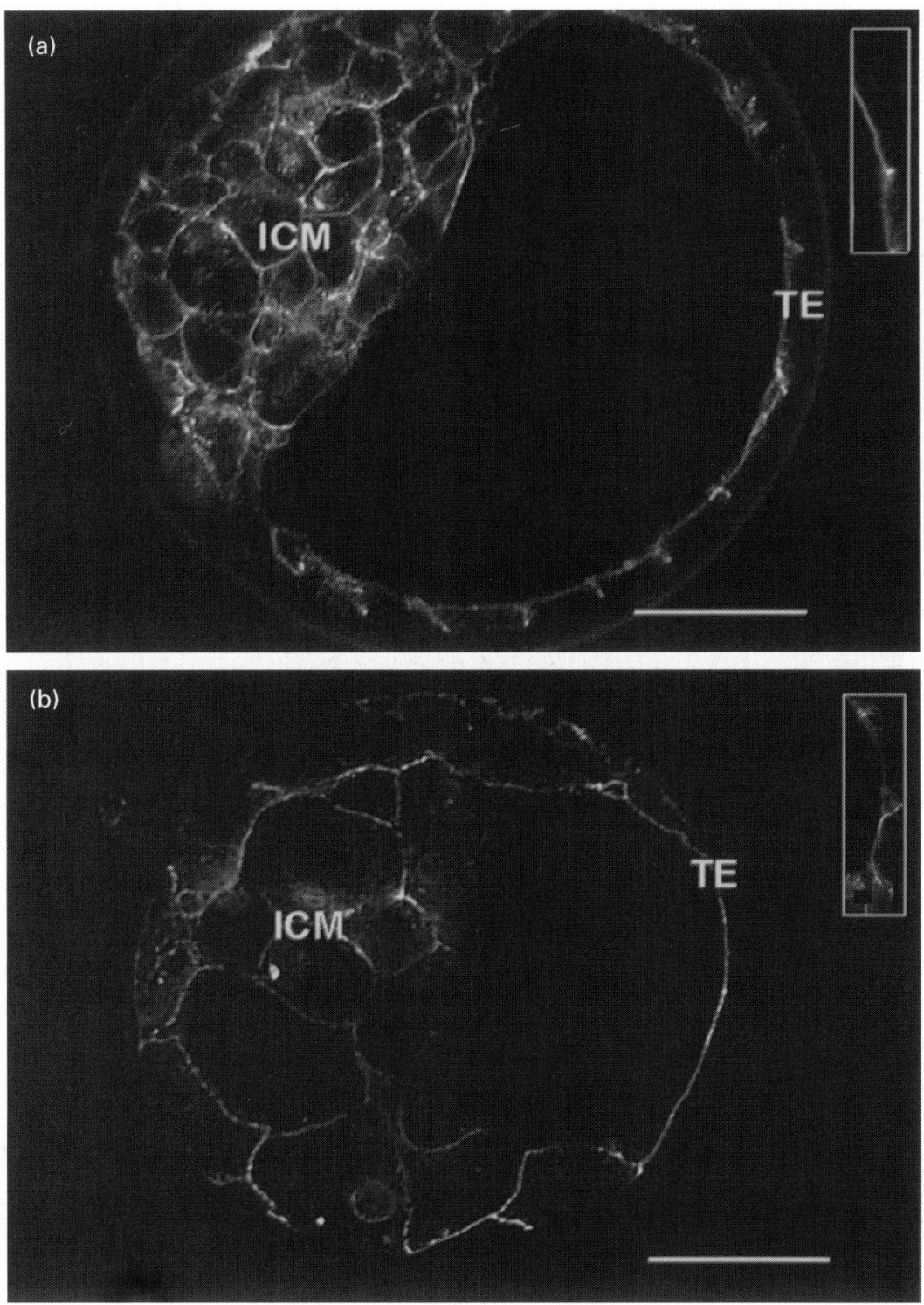

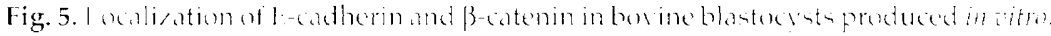
Both l:codherin (a) and B-catenin (h) are restricted to the basoldteral coll margins in trophedexterm collo (11). This restricted distribution is more apparent in enlarged

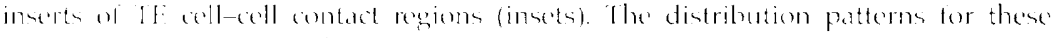

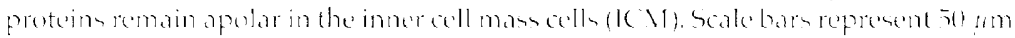

signal for \%()-1 was detected within the ICM (Figs 8c and 6k) ZO-1 staining was observed from the morula stage as cotoplasmic staining in peroxidase-1) AB-staned embryos (Fig. oh-k). The precise collular distributions displayed by all antisera and the low amounts of background staming in controls (figs 3i, $4 f$ and if) ensured that specitic immunolocalization patterns were observed.

\section{Discussion}

In mammalian preimplantation embryos, cell proliferation and differentiation after fertilisation culninate in the formation of a fludd-filled blastocyst. Vectoral fluid transpert and accumulation during blastocyst formation is attributed (1) the polaried "pithelial characteristics of the trophectoderm, which arise as a conseguence of differentiative exents initiated during compaction. Ecadherin mediated cell-cell adhesion associated with compaction symchromizes and orients coll polarity in the embrvo(Pratt it al, 1982, Johnson of al, 1986), representing a critical event in epithelial differentiation (Fleming et al., 1994; Larue et al., 1994; Reithmacher et al., 1995). The results of the present study show that tramsoripts and proteins encoding Ecatherin and its associaded cytoplasmic protein, $\beta$-catenin, are present throughout hovine pre-attachment development in ritro. These results suggest that these gene products have both oogenetic and embromic origins. The immuno- 


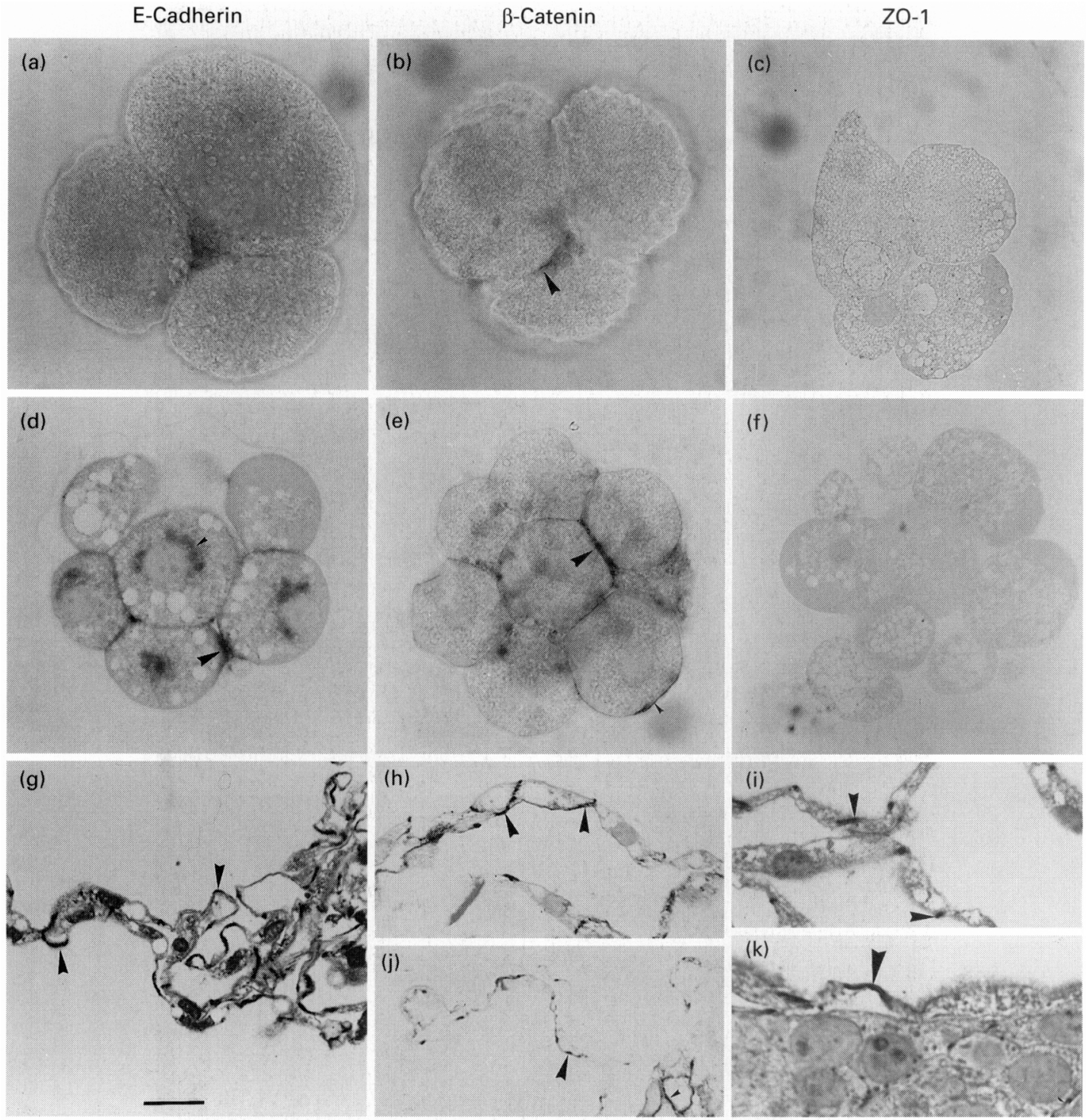

Fig. 6. Peroxidase diaminobenzidine (DAB) staining of bovine pre-attachment embryos for E-cadherin, $\beta$-catenin and zonula occludens protein 1 (ZO-1). $(a, d, g)$ E-cadherin; $(b, e, h, j) \beta$-catenin; $(c, f, i, k) Z O-1 .(a, b, c)$ Four-cell embryo stage; $(\mathrm{d}, \mathrm{e}, \mathrm{f}) 8$-16-cell embryo stage; $(\mathrm{g}, \mathrm{h}, \mathrm{i}, j, \mathrm{k})$ hatched blastocysts. E-cadherin immunoreactivity was not strongly detected until the 8-16-cell embryo stage, where it assumed a distribution associated with cell-cell contacts (large arrowhead) and perinuclear regions (small arrowhead) of each blastomere. In hatched blastocysts, E-cadherin immunoreactivity was confined to cell-cell contact regions of the TE (arrowheads), remaining undetected in apical TE cell surfaces. $\beta$-catenin immunoreactivity mirrored (arrowheads) the distribution observed for E-cadherin throughout bovine early development. In contrast, ZO-1 immunoreactivity was first detected in compacting morulae confined to adjacent apical regions of TE (large arrowheads). Scale bar represents $20 \mu \mathrm{m}$.

localization studies demonstrated that E-cadherin initially maintains an apolar distribution in blastomeres before compaction. Coincident with increased apposition of adjacent blastomeres and the onset of cavitation, these proteins adopt a polarized distribution in the basolateral membranes of trophectoderm cells, while maintaining an apolar distribution in ICM cell margins. The polarized Ecadherin distribution pattern observed in differentiating bovine trophectoderm is comparable with distributions reported for pig (Reima et al., 1993), and mouse early development (Vestweber et al., 1987; Reima, 1990; Larue et al., 1994; Riethmacher et al., 1995). In addition, Shehu et al. (1996) reported an identical E-cadherin distribution from the eightcell stage through to the blastocyst in embryos transferred to ligated sheep oviducts. Therefore, the results obtained from in vitro derived embryos indicate that culture has little impact on embryonic E-cadherin distribution patterns. The present study reports the distribution of E-cadherin polypeptides in earlier stages than that reported by Shehu et al. (1996). It is now clear that E-cadherin is present in cell margins from the one-cell zygote stage onward during bovine early development.

The integral role played by E-cadherin in blastocyst formation has been demonstrated in transgenic mouse lines, 

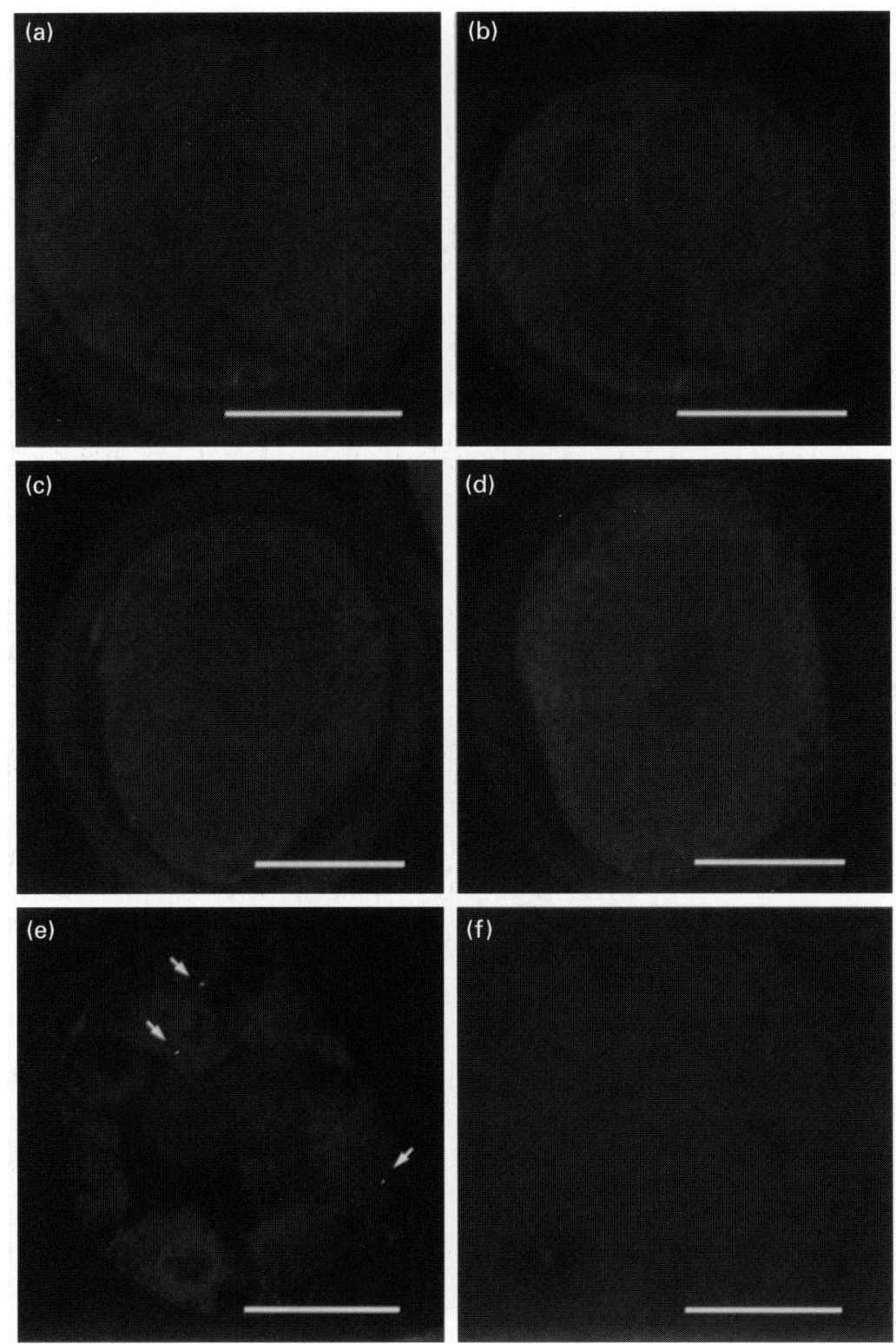

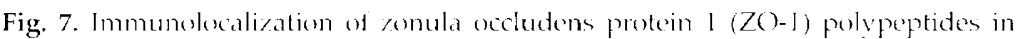
bovine deavige and morula stage (mbryos. Polypeptides eneoding ZO)-1 were undetectable he indirect immunofluoresence in (a) one-sell, (b) two-coll, (c) four-cell, and $(d)$ eight-coll burine embrras. (e) 70 -1 first becance detectable as punctate points of immunofluseresence between the outer cells of the morula (arrome) (f) Controls

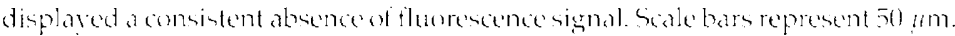

generated through gene targeting and homolegous recombination, that carry null mulations for E-cadherin (Larte et al., 1994; Riethmacher et al., 1995). Riethmadrer et al. (1995) reported that, initially; homozygous null embryos underwent compaction (an event contributed to residual oogenetic E-cadherin proteins) but failed to form normal blasterysts and never hatched from the zona pellucida. Removal of E-cadherin mediated coll-cell adhesion does not prevent cell polarization (Pratt it al., 1982; Johnson at al., $1986)$ but rather delas's and randomizes the orientation of cell polarity (Johnson ot al., 1986). Loss of ordered cell polarity in the embryo during compaction prevents the formation of a coherent trophectoderm cell layer (Larue ef al., 1994; Reithmacher 't al., 1995). Further characterization of these null mutant enbrvos has revealed that expression of both $(x-$ and $\beta$-catenin is downregulated and that $Z()-1$ expression is not detectahle (Ohsugi ot al., 1997). These studies clearly demonstrate that E-cadherin plays a pivotal role in the differentiation of the trophectoderm and, thus, plays a central role in supporting further embryonic development.

B-catenin binds to the cytoplasmic domain of the Ecatherin molecule and hares homology with the armatillo protein of Drosophliln which is involved in the wingless 

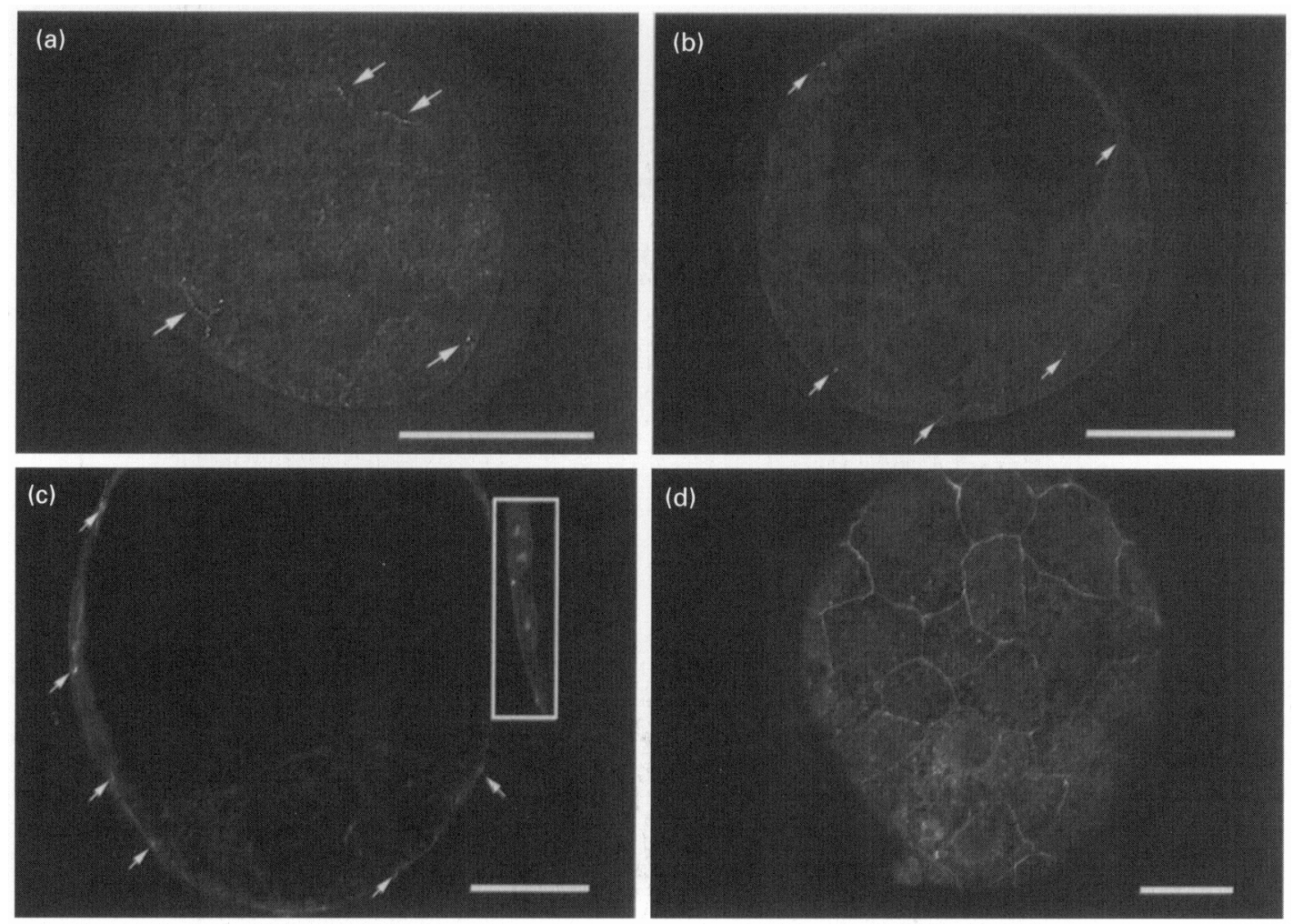

Fig. 8. Localization of zonula occludens protein 1 ( $\mathrm{ZO}-1)$ during the morula-to-blastocyst transition of bovine development in vitro. (a) By the mid-late 16-32-cell morula stage (arrows), regions of continuous immunofluorescence become apparent between the outer differentiating trophectoderm cells. (b) As cavitation progresses, ZO-1 fluorescence is restricted to the apical region of trophectoderm (TE) cell contact (arrows). (c) In the blastocyst, $\mathrm{ZO}-1$ immunofluorescence is restricted to apical TE contact points (arrows and inset) while remaining undetectable in the inner cell mass (ICM). (d) A cross-section plane through the apical TE surface of an expanded blastocyst displays the continuous ring of ZO-1 immunofluorescence that forms between these cells. Scale bars represent $50 \mu \mathrm{m}(\mathrm{a}-\mathrm{c})$ and $25 \mu \mathrm{m}(\mathrm{d})$.

intracellular signalling pathway (Kemler and Ozawa, 1989; McCrea et al, 1991; Hynes, 1992; Kemler, 1993). This protein also shifts to a polarized distribution in differentiating mouse trophectoderm (Haegel et al., 1995). The distribution pattern of $\beta$-catenin mRNAs and polypeptides has not been examined previously during bovine pre-attachment development. The results of the present study indicate that both mRNA and proteins encoding this gene are present in bovine embryos from the one-cell through to the blastocyst stage in patterns consistent with mouse development. Mouse embryos homozygous for $\beta$-catenin null mutations develop to the blastocyst stage and continue to progress until gastrulation (Haegel et al., 1995). It would appear that plakoglobin $/ \gamma$-catenin interactions with E-cadherin are sufficient to mediate trophectoderm differentiation (Haegel et al., 1995). It has been demonstrated that catenins associate with ZO-1 in Madin-Darby canine kidney cells during the early stages of tight junction assembly (Rajasekaran et al., 1996). Weak association of these catenin-ZO-1 complexes with E-cadherin may play a role in the shuttling of components of the tight junction to the lateral membranes mediating junction assembly (Rajasekaran et al., 1996). Bovine morulae immunostained with $\beta$-catenin antibodies in the present study demonstrated cytoplasmic localization of these polypeptides in addition to the membrane-bound distribution. Sheth of al. (1997) demonstrated that ZO-1 $\alpha^{+}$ isoform proteins first appear in compacting mouse morulae as perinuclear foci and then accumulate in the membrane between the outer blastomeres. These apparent spatial similarities in the localization of $\beta$-catenin and ZO- 1 further support a proposed shuttling role for $\beta$-catenin during tight junction assembly.

In contrast to E-cadherin and $\beta$-catenin proteins, ZO-1 polypeptides were not detected in early cleavage stage bovine embryos, but were first observed in morulae in differentiating outer blastomeres. These results are in contrast to previous findings in the bovine embryo, where ZO-1 polypeptides were not reported until the blastocyst stage (Shehu et al., 1996). The distribution pattern of ZO-1 consisted of punctate points of fluorescence that combined to form a thin fluorescent band confined to the apical contact regions of adjacent outer cells as the morula progressed towards the blastocyst stage. The two ZO-1 antibodies used in this study produced a similar detection pattern to that previously reported in mouse embryos (Fleming et al., 1989; Fleming and Hay, 1991), in which ZO-1 protein was localized at contact sites between outer blastomeres after compaction. Bovine embryos processed for peroxidase DAB staining with 
the rabbit polyclonal antibody revealed cytoplasmic as well as membrane staining in morulae coincident with cytoplasmic staining for $\beta$-catenin at this stage. Sheth $e t$ al. (1997) demonstrated that ZO- $1 \alpha^{+}$isoform proteins first appear in compacting mouse morulae as perinuclear foci and then accumulate in the membrane between the outer blastomeres. As compaction progresses, bovine embryos demonstrate a gradual establishment of continuous ZO-1 immunofluorescence along the apical regions of outer blastomeres. The establishment of zonular ZO-1 localization (Fleming et al., 1989, 1994) and tight junction formation coincide with the onset of cavitation (Ducibella and Anderson, 1975; McLaren and Smith, 1977; Pratt, 1985).

Our research is directed at providing an understanding of the mechanisms underlying blastocyst formation. These events are not well characterized during bovine early development and, owing to the limited availability of bovine early embryos derived in vivo for research, the majority of studies have investigated events in embryos derived in vitro. There are increasing concerns about the possible influence of varied culture environments on gene expression patterns. It is possible that the variation in the apparent intensity of ICM immunostaining observed for E-cadherin and $\beta$-catenin among blastocysts may also reflect in vitro effects on gene expression. Lower E-cadherin and $\beta$-catenin protein expression in the ICM may reflect embryo health and quality. However, direct comparison between embryos derived in vitro and in vivo is required to confirm this assumption.

In conclusion, the gene products encoding E-cadherin, $\beta$ catenin and ZO- 1 have been shown to be expressed and to maintain distribution patterns consistent with their predicted role in coordinating the events of trophectoderm differentiation in the early bovine embryo. Furthermore, the results of the present study indicate that bovine embryos derived in vitro express these important mediators of early development in patterns consistent with gene expression patterns associated with development in vivo.

The authors wish to thank J. Looye, P. De Sousa, D. Betts, Q. Winger and the ABEL Laboratories (University of Guelph) under the direction of S. Leibo, for their assistance with bovine ovary and oviduct collections, and PDS and D. Natale for critical review of the manuscript. Research supported by the Medical Research Council of Canada (MRC Operating grant number MT-12711). A. J. Watson is also supported by an MRC Scholarship.

\section{References}

Anderson JM, Stevenson BR, Jesaitis LA, Goodenough DA and Mooseker MS (1988) Characterization of ZO-1, a protein component of the tight junction from mouse liver and Madin-Darby canine kidney cells fournal of Cell Biology 106 1141-1149

Behrens J, Vakaet L, Friis R, Winterhager E, Van Roy F, Mareet MM and Birchmeier W (1993) Loss of epithelial differentiation and gain of invasiveness correlates with tyrosine phosphorylation of the $\mathrm{E}$ cadherin/beta-catenin complex in cells transformed with a temperaturesensitive v-SRC gene fournal of Cell Biology 120 757-766

Betts DH, MacPhee DJ, Kidder GM and Watson AJ (1997) Ouabain sensitivity and expression of $\mathrm{Na} / \mathrm{K}-\mathrm{ATPase}$ alpha- and beta-subunit isoform genes during bovine early development Molecular Reproduction and Development 46 114-126

Biggers JD, Bell JE and Benos DJ (1988) Mammalian blastocyst: transport functions in a developing epithelium American Journal of Physiology 255 C419-C432

Boller K, Vestweber D and Kemler R (1985) Cell-adhesion molecule uvomorulin is localized in the intermediate junctions of adult intestinal epithelial cells Journal of Cell Biology 100 327-332

Citi S, Sabanay H, Jakes R, Geiger B and Kendrick-Jones J (1988) Cingulin, a new peripheral component of tight junctions Nature 333 272-276

Citi S (1993) The molecular organization of tight junctions Journal of Cell Biology 121 485-489

Collins JE and Fleming TP (1995) Epithelial differentiation in the mouse preimplantation embryo: making adhesive cell contacts for the first time Trends in Biochemical Science 20 307-312

Davis CA (1993) Whole-mount immunohistochemistry Methods in Enzymology $225502-516$

De Sousa PA, Valdimarsson G, Nicholson BJ and Kidder GM (1993) Connexin trafficking and control of gap junction assembly in the mouse preimplantation embryo Development 117 1355-1367

Ducibelia T and Anderson E (1975) Cell shape and membrane changes in the eight-cell mouse embryo: prerequisites for morphogenesis of the blastocyst Developmental Biology $4745-58$

Fleming TP and Hay MJ (1991) Tissue-specific control of expression of the tight junction polypeptide ZO-1 in the mouse early embryo Development 113 295-304

Fleming TP and Johnson MH (1988) From egg to epithelium Annual Reviews of Cell Biology 4 459-485

Fleming TP, McConnell J, Johnson MH and Stevenson BR (1989) Development of tight junctions de novo in the mouse early embryo: control of assembly of the tight junction-specific protein, ZO-1 Journal of Cell Biology 108 1407-1418

Fleming TP, Garrod DR and Elsmore AJ (1991) Desmosome biogenesis in the mouse preimplantation embryo Development 112 527-539

Fleming TP, Hay MJ, Javed Q and Citi S (1993) Localization of tight junction protein cingulin is temporally and spatially regulated during early mouse development Development 117 1135-1144

Fleming TP, Butler L, Lei X, Collins J, Javed Q, Sheth B, Stoddart N, Wild A and Hay M (1994) Molecular maturation of cell adhesion systems during mouse early development Histochemistry 101 1-7

Furuse $M$, Hirase $T$, Itoh $M$, Nagafuchi $A$, Yonemura $S$, Tsukita $S$ and Tsukita S (1993) Occludin: a novel integral membrane protein localizing at tight junctions Journal of Cell Biology 123 1777-1788

Gumbiner BM and McCrea PD (1993) Catenins as mediators of the cytoplasmic functions of cadherins Journal of Cell Science 17 155-158

Gumbiner B and Simons K (1987) Role of uvomorulin in the formation of epithelial occluding junctions. In Junctional Complexes of Epithelial Cells, Ciba Foundation Symposium 125 pp 168-186 Ed. Sir Michael Stoker. John Wiley and Sons Ltd, Chichester

Gumbiner B, Stevenson B and Grimaldi A (1988) The role of the cell adhesion molecule uvomorulin in the formation and maintenance of the epithelial junctional complex Journal of Cell Biology 107 1575-1587

Haegel H, Larue L, Ohsugi M, Fedorov L, Herrenknecht $K$ and Kemler $R$ (1995) Lack of $\beta$-catenin affects mouse development at gastrulation Development 121 3529-3537

Harvey MB, Arcellana-Panlilio MY, Zhang $X$, Schultz GA and Watson AJ (1995) Expression of genes encoding antioxidant enzymes in preimplantation mouse and cow embryos and primary bovine oviduct cultures employed for embryos coculture Biology of Reproduction $\mathbf{5 3}$ $532-538$

Hay-Schmidt A (1995) The larval nervous system of Polygordius lacteus Schneider, 1868 (Polygordidae, Polychaeta): immunocytochemical data Acta Zoologica 76 121-140

Hulsken J, Birchmeier W and Behrens J (1994) E-cadherin and APC compete for the interaction with beta-catenin and the cytoskeleton fournal of Cell Biology 127 2061-2069

Hynes RO (1992) Specificity of cell adhesion in development: the cadherin superfamily Current Opinion in Genes and Development 2 621-624

Johnson MH, Maro B and Takeichi M (1986) The role of cell adhesion in the synchronization and orientation of polarization in 8-cell mouse blastomeres Journal of Embryology and Experimental Morphology 93 239-255

Kemler R (1993) From cadherins to catenins: cytoplasmic protein interactions and regulation of cell adhesion Trends in Genetics $9317-321$

Kemler R and Ozawa M (1989) Uvomorulin-catenin complex: cytoplasmic anchorage of a $\mathrm{Ca}^{2+}$-dependent cell adhesion molecule BioEssays 11 88-91

Kidder GM (1993) Genes involved in cleavage, compaction and blastocyst 
formation. In Genes in Mammalian Development pp 45-47. Wiley-Liss Inc., New York

Larue L, Ohsugi M, Hirchenhain J and Kemler R (1994) E-cadherin null mutant embryos fail to form a trophectoderm epithelium Proceedings of the National Academy of Sciences USA 91 8263-8267

Li CK and Poznansky MJ (1990) Characterization of the ZO-1 protein in endothelial cells and other cell lines Journal of Cell Science 97 231-237

McLaren A and Smith R (1977) Functional test of tight junctions in the mouse blastocyst Nature 267 351-353

McCrea PD, Turck CW and Gumbiner B (1991) A homologue of the armadillo protein in Drosophila (plakoglobin) associated with E-cadherin Science $\mathbf{2 5 4}$ 1359-1361

McNeill H, Ryan TA, Smith SJ and Nelson WJ (1993) Spatial and temporal dissection of intermediate and early events following cadherin-mediated epithelial cell adhesion Journal of Cell Biology 120 1217-1226

Marrs JA, Napolitano EW, Murphy-Erdosh C, Mays RW, Reichardt LF and Nelson WJ (1993) Distinguishing roles of the membrane-cytoskeleton and cadherin mediated cell-cell adhesion in generating different $\mathrm{Na}^{+}, \mathrm{K}^{+}$-ATPase distributions in polarized epithelia Journal of Cell Biology 123 149-164

Nagafuchi A and Takeichi M (1988) Cell binding function of E-cadherin is regulated by the cytoplasmic domain EMBO Journal $73679-3684$

Nagafuchi A, Shirayoshi Y, Okazaki K, Yasuada K and Takeichi M (1987) Transformation of cell adhesion properties by exogenously introduced Ecadherin cDNA Nature $329341-343$

Nollet F, Berx G, Molemans F and van Roy F (1996) Genomic organization of the human beta-catenin gene (CTNNB1) Genomics 32 413-424

Ohsugi M, Larue L, Schwarz H, and Kemler R (1997) Cell-junctional and cytoskeletal organization in mouse blastocysts lacking E-cadherin Developmental Biology 185 261-271

Ozawa M, Ringwald M and Kemler R (1990) Uvomorulin-catenin complex formation is regulated by a specific domain in the cytoplasmic region of the cell adhesion molecule Proceedings of the National Academy, of Sciences USA 87 $4246-4250$

Parish JJ, Susko-Parrish JL, Leibfried-Rutledge ML, Critser ES, Eyestone WH and First NL (1986) Bovine in vitro fertilization with frozen-thawed sperm Theriogenology 25 591-600

Pratt HPM (1985) Membrane organization in the preimplantation mouse embryo Journal of Embryology and Experimental Morphology 90 101-121

Pratt HPM, Ziomek CA, Reeve WJD and Johnson MH (1982) Compaction of the mouse embryo: an analysis of its components Joumal of Embryology and Experimental Morphology 70 113-132

Rajasekaran AK, Hojo M, Huima T and Rodriguez-Boulan E (1996) Catenins and zonula occludens- 1 form a complex during early stages in the assembly of tight junctions Journal of Cell Biology 132 451-463

Ranscht B (1994) Cadherins and catenins: interactions and functions in embryonic development Current Opinion in Cell Biology 6 740-746

Reima I (1990) Maintenance of compaction and adherent-type junctions in mouse morula stage embryos Cell Differentiation and Development 29 143-153

Reima I, Lehtonen E, Virtanen I and Flèchon J-E (1993) The cytoskeleton and associated proteins during cleavage, compaction and blastocyst differentiation in the pig Differentiation 54 35-45

Riethmacher D, Brinkmann V and Birchmeier C (1995) A targeted mutation in the mouse E-cadherin gene results in defective preimplantation development Proceedings of the National Academy of Sciences USA 92 855-859

Rodriguez-Boulan E and Nelson WJ (1989) Morphogenesis of the polarized epithelial cell phenotype Science 245 718-725

Shehu D, Marsicano G, Flechon J-E and Galli C (1996) Developmentally regulated markers of in vitro-produced preimplantation bovine embryos Zygote 4 109-121

Sheth B, Fesenko I, Collins JE, Moran B, Wild AE, Anderson JM and Fleming TP (1997) Tight junction assembly during mouse blastocyst formation is regulated by late expression of $\mathrm{ZO}-1 \alpha^{+}$isoform Development 124 2027-2037

Siliciano JD and Goodenough DA (1988) Localization of the tight junction protein, ZO-1, is modulated by extracellular calcium and cell-cell contact in Madin-Darby canine kidney epithelial cells fournal of Cell Biology 107 2389-2399

Stevenson BR, Siliciano JD, Mooseker MS and Goodenough DA (1986) Identification of ZO-1: a high molecular weight polypeptide associated with the tight junction (zonula occludens) in a variety of epithelia Journal of $\mathrm{Cell}$ Biology 103 755-766

Stevenson BR, Anderson JM and Bullivant S (1988) The epithelial tight junction: structure, function and preliminary biochemical characterization Molecular Cell Biochemistry 83 129-145

Su LK, Vogelstein B and Kinzler KW (1993) Association of the APC tumor suppressor protein with catenins Science 262 1734-1737

Takeichi M (1988) The cadherins: cell-cell adhesion molecules controlling animal morphogenesis Development $102639-655$

Temeles GL, Ram PT, Rothstein JL and Schultz RM (1994) Expression patterns of novel genes during mouse preimplantation embryogenesis Molecular Reproduction and Development 37 121-129

Vestweber D, Gossler A, Boller K and Kelmer R (1987) Expression and distribution of cell adhesion molecule uvomorulin in mouse preimplantation embryos Developmental Biology 124 451-456

Watson AJ (1992) The cell biology of blastocyst development Molecular Reproduction and Development 33 492-504

Watson AJ, Damsky CH and Kidder GM (1990) Differentiation of an epithelium: factors affecting the polarized distribution of $\mathrm{Na}^{+} / \mathrm{K}^{+}$-ATPase in mouse trophectoderm Developmental Biology 141 104-114

Watson AJ, Kidder GM and Schultz G (1992a) How to make a blastocyst Biochemical and Cellular Biology 70 849-855

Watson AJ, Hogan A, Hahnel A, Wiemer KE and Schultz GA (1992b) Expression of growth factor ligand and receptor genes in the preimplantation bovine embryo Molecular Reproduction and Development 31 87-95

Watson AJ, Watson PH, Arcellana-Panlilio M, Warnes D, Walker SK, Schultz GA, Armstrong DT and Seamark RF (1994) A growth factor phenotype map for ovine preimplantation development Biology of Reproduction 50 725-733

Wiemer KE, Watson AJ, Polanski V, McKenna AI, Fick GH and Schultz GA (1991) Effects of maturation and co-culture treatments on the developmental capacity of early bovine embryos Molecular Reproduction and Development 30 330-338

Wiley LM, Kidder GM and Watson AJ (1990) Cell polarity and development of the first epithelium BioEssays 12 67-73

Winger QA, de los Rios P, Han VKM, Hill DJ and Watson AJ (1997) Bovine oviductal and embryonic insulin-like growth factor binding proteins: possible regulators of embryotrophic insulin-like growth factor circuits Biology of Reproduction 56 1415-1423

Xia P, Han VKM, Viuff D, Armstrong DT and Watson AJ (1996) Expression of insulin-like growth factors in two bovine oviductal cultures employed for embryo co-culture Journal of Endocrinology 149 41-53

Xu KP, Yadav BR, Rorie RW, Plante L, Betteridge KJ and King WA (1992) Development and viability of bovine embryos derived from oocytes matured and fertilized in vitro and co-cultured with bovine oviductal epithelial cells journal of Reproduction and Fertility 94 33-43 